\title{
PROSPER: A New Framework for Positive Education
}

\author{
Toni Noble ${ }^{1 *}$ and Helen McGrath ${ }^{2}$
}

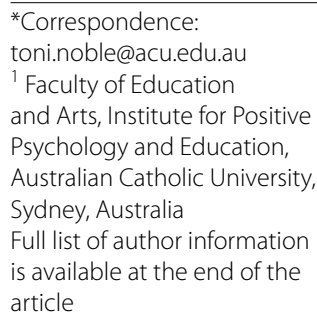

\begin{abstract}
Positive psychology is the study of the conditions and processes that contribute to optimal flourishing in people, groups and organisations. This paper outlines the PROSPER framework, an organising tool for the implementation of Positive Education, a relatively new direction which represents the application of Positive Psychology research to educational contexts. The word 'PROSPER' communicates the purpose of the framework and is also an acronym that highlights the seven key elements that have been identified as contributing to wellbeing: Positivity, Relationships, Outcomes, Strengths, Purpose, Engagement, and Resilience. Confirmatory data on the usefulness of the PROSPER framework, obtained through surveys conducted with researchers from the Institute of Positive Psychology and Education (ACU) and fifty-four educators from four different schools, is presented and discussed. A rationale for the inclusion of the seven components is provided and the PROSPER framework is then further supported by reference to the evidence-informed school and classroom practices that contribute to student wellbeing and achievement and help to build schools as enabling institutions.
\end{abstract}

Keywords: Positive psychology, Positive education, Positivity, Relationships, Outcomes, Strengths, Purpose, Engagement, Resilience, Social-emotional learning, Educational policy

\section{Background}

Interest in positive psychology, and its application in education, health, communities and organisations, has grown exponentially over the last 15 years. The goal of positive psychology is to provide the conditions and processes that contribute to flourishing or optimal functioning of people, groups and institutions (Gable and Haidt 2005). This paper outlines the PROSPER framework as an organiser for positive psychological interventions that can help people, groups, organisations or communities to achieve this goal. The term 'to prosper' is defined as to thrive and succeed in a healthy way; to flourish (Oxford dictionary; Merriam-Webster Dictionary). Flourishing refers to the experience of life going well and equates with a high level of wellbeing and it epitomises mental health (Huppert and So 2013; Keyes 2002; Ryff and Singer 1998). It is a combination of feeling good and functioning effectively (Huppert and So 2013). Use of the term PROSPER reflects the intended purpose of this framework which is as an organiser for the multi-dimensional components that contribute to flourishing. The PROSPER acronym

\section{Springer}

(c) 2015 Noble and McGrath. This article is distributed under the terms of the Creative Commons Attribution 4.0 International License (http://creativecommons.org/licenses/by/4.0/), which permits unrestricted use, distribution, and reproduction in any medium, provided you give appropriate credit to the original author(s) and the source, provide a link to the Creative Commons license, and indicate if changes were made. 
stands for Positivity, Relationships, Outcomes, Strengths, Purpose, Engagement, and Resilience.

The PROSPER framework has several similarities to Seligman's (2011) earlier PERMA model of wellbeing (Positive emotions, Engagement, Relationships, Meaning and Accomplishment), but specifically includes two additional significant components: Strengths and Resilience. Resilience is considered an important indicator of wellbeing as illustrated in Huppert and So's (2013) model of flourishing used to measure wellbeing of citizens in twenty-three European countries with 43,000 participants. The Huppert and So model of flourishing includes the following components that are also included in the PROSPER framework: positive emotions, optimism (Positivity), positive relationships (Relationships), competence (Outcomes), meaning (Purpose), engagement (Engagement) and resilience (Resilience). The additional elements in the Huppert and So model: self-esteem, vitality and emotional stability have been subsumed in the PROSPER elements; emotional stability under Resilience and vitality under Positivity. The construct self respect is included as a character strength in PROSPER instead of self esteem given the reported concerns with the self esteem construct (Baumeister et al. 2005; Seligman et al. 1995) More explanation for these differences is provided in Noble and McGrath (2015). One additional element in PROSPER which is not in their model is the construct of Strengths. The component of Strengths is included as a distinct category in PROSPER because the deployment of one's strengths is seen as central to wellbeing theory (Seligman 2011).

Feedback on the usefulness of the acronym PROSPER and the validity of the seven theoretical and evidence-informed components that are the core of the PROSPER framework was sought from fourteen researchers and professors at the Institute of Positive Psychology and Education (IPPE) at the Australian Catholic University. All IPPE members supported the inclusion of all seven components as well as providing constructive feedback on the omission of some of the details for each component (such as suggesting the inclusion of mindfulness in the Positivity component). Each component of PROSPER meets Seligman's three criteria for an element of wellbeing i.e. (1) each element contributes to wellbeing, (2) each element can be defined and measured independently of the other elements and (3) many people pursue the element for it's own sake (Seligman 2011, p. 16). An assessment tool for measuring the PROSPER components for student wellbeing is under development.

Feedback on the usefulness of the PROSPER framework was also sought from a convenience sample of educators. All of the teachers and principals who attended a oneday workshop on student wellbeing were asked for their feedback on the usefulness and relevance of the PROSPER framework at the end of the workshop. The compulsory workshop was inclusive of all teaching staff at four government primary schools, not just those teachers with designated responsibility for student wellbeing or social-emotional learning. The teachers were invited to respond anonymously to a seven-item questionnaire using a 5-point Likert scale from strongly disagree to strongly agree. Fifty-four respondents posted their survey responses face down in a box as they exited the workshop. Positive education was a new discipline for these schools and therefore the teachers were arguably less likely to have a preconceived idea of the usefulness or otherwise of a Positive Educational framework for their school practices. All respondents (100\%) 
agreed or strongly agreed that the PROSPER framework would help to provide a common language about wellbeing within their school and across schools. Most respondents (90\%) agreed or strongly agreed that it makes (a) the core components of wellbeing easy-to-remember and (b) is easy to communicate to everyone in their school community because of the relevant nature of the acronym. Most (96\%) also agreed or strongly agreed that the PROSPER framework would help staff to reflect on their practice for student wellbeing and $89 \%$ also agreed or strongly agreed that the framework has the potential as an audit tool for identifying their school's current successful practices for student wellbeing as well as identifying the gaps.

In this paper the PROSPER framework is applied to the educational context. This application of PROSPER in education seems timely given Seligman's (2011) challenge to policy makers to develop a new measure of prosperity, beginning early in life:

'the time has come for a new prosperity, one that takes flourishing seriously as a the goal for education and of parenting. Learning to value and to attain flourishing must start early-in the formative years of schooling-and it is this new prosperity, kindled by positive education, that the world can now choose' (Seligman 2011, p. 97).

\section{Using the Prosper Framework in Schools}

PROSPER within a school context incorporates the evidence-informed school practices that have the potential to enhance student wellbeing and achievement and build schools as enabling institutions. The PROSPER organiser builds on the authors' two earlier versions of a positive psychology framework for education. The first prototype evolved as an outcome of the authors' co-development of the Australian Government Scoping Study on Approaches to Student Wellbeing (Noble and McGrath 2008a) and the second prototype is titled the Positive Educational Practices (PEPs) Framework (Noble and McGrath 2008b). PROSPER has some similarities with Geelong Grammar School's (GGS) Positive Education framework outlined by Norrish (2015). The GGS' domains are Positive emotions, Positive Relationships, Positive Accomplishment, Character Strengths, Positive Purpose, Positive Engagement and Positive Health and Resilience.

The authors' first initiative in applying the principles of positive psychology to education was incorporated in their Bounce Back Wellbeing and Resilience program published in 2003 and revised in 2011(McGrath and Noble 2003, 2011). Bounce Back was developed as a whole school primary and middle school wellbeing program to promote a positive school culture as well as provide a multi-faceted wellbeing curriculum for classroom teachers to teach to their students. PROSPER is now offered as an organising framework for the evidence-based school components of student wellbeing and Bounce Back is provided as program that focuses on these components through teaching strategies, school and classroom organisation, working with parents and the provision of focused curriculum units. The Bounce Back curriculum units are Emotions, Humour and the Bright Side (Positivity), Relationships and Core Values units (Relationships), a unit on Success unit that incorporates Outcomes, Strengths, Purpose and Engagement and the People Bouncing Back and Courage units (Resilience).

Positive Education is defined within the PROSPER context as: 
'the integration of the core principles of positive psychology with the evidenceinformed structures, practices and programs that enhance both wellbeing and academic achievement. The aim of positive education is to enable all members of a school community to succeed and prosper.

Figure 1 outlines the PROSPER acronym and illustrates each of the seven components with a range of school and classroom practices that contribute to student wellbeing.

\section{Positivity}

Positivity can be defined simply 'as the state of being positive'. The term 'positivity' is employed by Barbara Fredrickson (2009) to include the positive meanings and optimistic attitudes that trigger positive emotions. Positivity also incorporates the long-term impact that positive emotions have on one's character, relationships, communities and environment. As outlined in Figure 1 a focus on Positivity encourages educators to provide classroom and school opportunities for students to experience and amplify positive emotions such as feeling connected and feeling safe. Positivity also encourages educators to explicitly teach students the values and skills for expressing gratitude and thinking optimistically.

\section{Positive Emotions}

People who frequently experience and express positive emotions tend to be more resilient (Fredrickson and Tugade 2004), more socially connected (Mauss et al. 2011), and more likely to function at optimal levels (Fredrickson and Losada 2005; Mauss et al. 2011). Fredrickson's (2013) 'broaden and build' model hypothesises that experiencing positive emotions, such as belonging, safety, interest and curiosity, amusement, joy and gratitude, can broaden an individual's thoughts and actions in a positive and helpful way. Positive emotions, even when fleeting, are hypothesised to accumulate and compound over time in ways that incrementally build people's personal resources such as their physical, intellectual, social and psychological resources (Fredrickson 2013). Huebner and Hills (2014) have concluded, from the available research evidence conducted with children and adolescents, that '...frequent positive emotions appear to facilitate more positive life experiences in many important arenas of [their] life' (p774). For example in one school study involving 293 students in grades 7-10, Reschly et al. (2008) demonstrated that experiencing frequent positive emotions at school was associated with higher levels of student engagement and adaptive coping.

\section{Feeling Connected}

Self-determination theory posits that the need to belong and feel connected is one of the three basic human needs (Deci and Ryans 2000). In a study of almost 700 students across two high schools, students' sense of belonging to their school was identified as the most significant variable for explaining student psychological wellbeing (Bizumic et al.2009). The more connected and accepted the students felt, the less likely they were to report anxiety, depression, loss of emotional control and aggression, and the less likely their teachers rated their behaviour as disruptive. Osterman (2000) found in her research review that when students experience a sense of belonging and acceptance at school 


\begin{tabular}{|c|c|}
\hline $\begin{array}{l}\text { PROSPER SCHOOL } \\
\text { PATHWAYS }\end{array}$ & $\begin{array}{l}\text { EXAMPLES OF SCHOOL \& CLASSROOM PRACTICES \& } \\
\text { STRUCTURES }\end{array}$ \\
\hline $\begin{array}{l}\text { Encouraging POSITIVITY } \\
\text { Supporting students to develop } \\
\text { positivity skills and experience } \\
\text { positive emotions }\end{array}$ & $\begin{array}{l}\text { - Provision of opportunities for students to experience and } \\
\text { amplify positive emotions and build positive learning } \\
\text { environments e.g through the use of music, dance, humour, } \\
\text { cooperative learning tasks } \\
\text { - Explicit teaching of the values and skills needed for a Positive } \\
\text { Mindset } \\
\text { Optimistic thinking, positive tracking, positive } \\
\text { conversion, hopeful thinking and expressing gratitude } \\
\circ \quad \text { Mindfulness } \\
\text { - Provision of opportunities to practise these skills }\end{array}$ \\
\hline $\begin{array}{l}\text { Building RELATIONSHIPS } \\
\text { Supporting students to develop } \\
\text { the social skills and pro-social } \\
\text { values that underpin positive } \\
\text { relationships and building } \\
\text { positive relationships within the } \\
\text { school }\end{array}$ & $\begin{array}{l}\text { - Strategies for developing: } \\
\text { - a safe \& supportive school culture } \\
\text { - positive student-teacher relationships, } \\
\text { - positive student-peer relationships } \\
\text { - Explicit teaching of somily \& school-community relationships and pro-social values } \\
\text { - Provision of opportunities to practise these social skills } \\
\text { Interpersonal structures that facilitate relationships e.g. cooperative learning } \\
\text { groups, cross-age teams, cooperative games, peer support and performance } \\
\text { groups. }\end{array}$ \\
\hline $\begin{array}{l}\text { Facilitating OUTCOMES } \\
\text { Provision of optimal learning } \\
\text { environments and opportunities } \\
\text { to learn specific skills that } \\
\text { enhance students' outcomes \& } \\
\text { accomplishment }\end{array}$ & $\begin{array}{l}\text { - Adoption of evidence-informed teaching strategies } \\
\text { - Explicit teaching of skills for: } \\
\text { - Grganisation } \\
\text { - Goal achievement (e.g. effort, persistence + willpower (grit) and problem- } \\
\text { - Effective studying } \\
\text { - The use of critical and creative thinking tools that challenge and scaffold }\end{array}$ \\
\hline $\begin{array}{l}\text { Focusing on STRENGTHS } \\
\text { Taking a strengths-based } \\
\text { approach with students, teachers } \\
\text { and the whole school community }\end{array}$ & $\begin{array}{l}\text { Adoption of strengths-based approaches to organisation, } \\
\text { curriculum and planning which results in: } \\
\text { - Students identifying, exploring and applying their character and } \\
\text { ability strengths in lessons, in extra-curricular and leadership } \\
\text { activities } \\
\text { - Teachers using task differentiation based on students' } \\
\text { character \& ability strengths } \\
\text { - School psychologists and coaches using strengths-based } \\
\text { approaches } \\
\text { recognition and application of teacher and parent strengths and } \\
\text { collective strengths using change strategies such as } \\
\text { appreciative inquiry }\end{array}$ \\
\hline $\begin{array}{l}\text { Fostering a sense of } \\
\text { PURPOSE } \\
\text { Supporting students to develop a } \\
\text { sense of purpose and meaning }\end{array}$ & $\begin{array}{l}\text { Provision of opportunities for students to: } \\
\text { - participate in student-owned and student-directed activities } \\
\text { - } \text { me involved with community service or service learning } \\
\text { make contributions to the school through 'student voice' \& } \\
\text { - undicipation in decision-making about aspects of the school } \\
\text { - undertake leadership roles } \\
\text { - explore spirituality }\end{array}$ \\
\hline $\begin{array}{l}\text { Enhancing ENGAGEMENT } \\
\text { Providing opportunities for high } \\
\text { student engagement }\end{array}$ & $\begin{array}{l}\text { Adoption of: } \\
\text { - } \text { evidence-informed teaching \& learning strategies } \\
\text { - } \text { activionship-based teaching strategies } \\
\text { - curriculum differentiation and extra-curricular activities so } \\
\text { students experience 'flow' }\end{array}$ \\
\hline $\begin{array}{l}\text { Teaching RESILIENCE } \\
\text { Supporting students to develop } \\
\text { the skills and attitudes that } \\
\text { underpin resilient behaviour. }\end{array}$ & $\begin{array}{l}\text { Explicit teaching of skills for: } \\
\text { - Coping and acting resiliently in both personal and academic } \\
\text { contexts } \\
\text { - Acting with courage } \\
\text { - Good decision-making } \\
\text { Self management }\end{array}$ \\
\hline
\end{tabular}

Figure 1 The PROSPER framework: Seven School Pathways that enable all students to PROSPER.

they are more likely to participate in learning activities, support each other, behave in accordance with school rules and expectations and achieve at a higher level. Students who feel connected to their school are also less likely to engage in health-compromising 
behaviour (Blum and Libbey 2004; Bond et al. 2001) and more likely to graduate from high school (Miltich et al. 2004). A sense of belonging is the result of many small steps taken by a school such as: the extensive use of cooperative learning, the provision of lunchtime clubs and extracurricular programs, and the adoption of peer support structures such as cross-age buddy systems and peer tutoring (Stanley and McGrath 2006).

\section{Feeling Safe}

Feeling safe and protected from bullying is directly linked to feeling supported and cared for by teachers and connected to peers (Flashpohler et al. 2009). All students feel less safe when they are aware that bullying is occurring in their school, even if they haven't been bullied themselves (e.g.Janson et al. 2009). A study by Strom et al. (2013), involving 56 schools in Norway, found that students in schools that had higher levels of bullying performed worse academically than other schools where this was not the case. Similarly Konishi et al. (2010) found the overall levels of achievement in both reading and math were lower in schools with higher levels of bullying. Researchers are increasingly seeing bullying as a socio-ecological and multifaceted problem that requires a multifaceted solution. We suggest that addressing bullying behaviours is one side of the coin-the other side is implementing the PROSPER pathways which contribute to a positive school climate.

\section{Feelings of Enjoyment and Amusement}

Laughter has been shown to relax the body and trigger pleasure through the release of dopamine into the brain (Reiss et al. 2003). It also has the capacity to reduce stress (Bennett and Lengacher 2009; Colom et al. 2011) and improve immune functioning (Berk et al. 2001). Studies confirm that finding the humorous side of a situation or participating in humour-based activities can also be an effective (and optimistic) strategy for coping resiliently with difficult times in one's life and for reducing anxiety (Booth-Butterfield et al. 2007). Humour can also increase the capacity to tolerate physical pain (e.g. Zweyer et al. (2004). In their review of research studies that have focused on the impact of humour in educational contexts, Banas et al. (2011) concluded that the use of positive, non-aggressive humour is associated with a more interesting and relaxed learning environment, more positive perceptions by students of the teacher who uses it, a stronger motivation to learn, and more enjoyment of the content and the tasks. Humour can be used in many ways within a classroom context (e.g. see McGrath and Noble 2011). The use of humour can be a style of interaction, an approach to teaching and learning (e.g. using cartoons or humorous images in a slide presentation or playing educational games), a curriculum activity (e.g. conducting a class survey to identify the most amusing of four different jokes or cartoons, the reading and analysis of funny books, or the writing of funny stories or poems) and, when used appropriately, it can also be an effective coping skill (e.g. laughing at your own silly mistake can help to keep things in perspective).

\section{Positive Mindset}

\section{Expressing Gratitude and Appreciation}

Gratitude has been defined as 'a higher-level moral emotion that enables people to notice, understand and capitalise on beneficial exchanges with others' (Froh and Bono 
2011, p. 1). When people are grateful, they notice and appreciate the good things that happen to them and express thanks to those who are responsible (Emmons 2007). Gratitude is thought to mature gradually in childhood as children become increasingly capable of making accurate judgements about a benefactor's intentions as well the cost to the benefactor of their actions (Froh and Bono 2011; Emmons and Shelton 2002).

In a study conducted by Froh et al. (2008), students aged 11-14 years participated in a gratitude education program over 2 weeks that encouraged them to count up to five things they were grateful for each day. In comparison to students in the control group, those who had received this training demonstrated (at a 3-week follow up evaluation) higher levels of optimism, positive mood and life satisfaction as well as more satisfaction with their experiences at school. Similar effects as a result of 'gratitude interventions' have been identified in other studies (e.g. Froh and Bono 2011). Strategies for encouraging students to feel and express gratitude include the creation of 'Gratitude Bulletin Boards' around the school on which everyone is encouraged to write down the things they are grateful for about the school, a digital Classroom Gratitude Book which features one page from each student and the creation of a classroom 'Appreciation Station' (McGrath and Noble 2011), where students can prepare and send emails, cards or letters to express their appreciation and gratitude to people in the school community and beyond.

\section{Mindfulness}

There is increasing interest within the Positive Psychology movement in the benefits of mindfulness and acceptance on wellbeing. Mindfulness has been described as having two components. The first component is the self-regulation of attention. The second component is the adoption of a curious, open and accepting orientation toward one's experiences in the present moment (Bishop et al., 2004). Fredrickson et al. (2008) found that the mindfulness practice of 'loving-kindness meditation' produced increases over time in daily experiences of positive emotions that, in turn, increased personal resources (e.g. purpose in life, social support). A review (Meiklejohn et al. 2012) of 14 studies that integrated mindfulness training in schools found the following student improvements: social skills, academic skills, emotional regulation, self esteem, positive mood and better memory and attention. Students also showed less anxiety, stress and fatigue. Schools can introduce mindfulness by using one or more of the following approaches (Niemiec 2014): (1) a formal approach in which a designated time of up to $10 \mathrm{~min}$ per day is allocated to mindfulness practices. Most practices focus on breathing such as the free mindfulness scripts on http://www.smilingmind.com.au, (2) an informal approach in which students are encouraged to slow down, pause, breathe slowly, become more aware of their feelings and behaviour when they feel overwhelmed or anxious and (3) an in-themoment approach in which students are encouraged to return to the present moment when they lose attention and to practise being in the present when, for example, working, playing, listening or eating.

\section{Relationships}

Schools are essentially social contexts and as Chris Peterson (2013) famously said 'relationships matter'. A focus on relationships in schools means that school staff take 
strategic steps to intentionally build positive relationships such as peer relationships, teacher-student relationships, staff relationships and parent-school relationships (see Figure 1).

\section{Positive Peer Relationships}

One of the strongest themes across educational research is the significant role that positive school-based peer relationships play in the life of children and adolescents (e.g. Gristy 2012) and the positive contribution that such relationships can make to a young person's sense of belonging, engagement, motivation and achievement, prosocial behaviour, student wellbeing and resilience (e.g. Caprara et al. 2000, Martin and Dowson 2009; Rubin et al. 2006; Wentzel et al. 2004; Zins et al. 2004). A comprehensive meta-analysis by Roseth et al. (2008) carried out with 148 studies from eleven countries found that positive peer relationships explained $33-40 \%$ of the variance in academic achievement. Friendships can provide students with social and emotional support, opportunities to learn and practise empathy, protection against bullying and social isolation (e.g. Qualter 2003; Schwartz et al. 2000) and opportunities to safely discuss moral dilemmas and develop socio-moral reasoning (Schonert-Reichel 1999). Research (e.g. Hartup and Stevens 1997) suggests that it is probably the cumulative experience of school-based reciprocated friendships over time that has the most positive effects, not just one particular friendship at one point in time.

Positive peer relationships are more likely when students experience opportunities to learn and practise using prosocial values that emphasise harmony and concern for others such as respect, cooperation, acceptance of differences, compassion, friendliness and inclusion (McGrath and Noble 2011). The teaching of specific social and emotional (SEL) skills enable students to demonstrate these values in action. These include social skills such as sharing, cooperation, anger management, respectful disagreeing, negotiation, playing fairly and being a good winner and loser, having an interesting conversation, telling a funny story and managing a disagreement well (McGrath and Francey 1991; McGrath and Noble 2010, 2011). The findings of a large-scale meta-analysis of SEL programs (Durlak et al. 2011) confirmed the positive impact of such programs on student learning and achievement. This meta-analysis focused on 213 school-based, universal social-emotional learning (SEL) programs and involved over 270,000 students from primary-school entry to year 12 . Compared to those in the control group, students who participated in social-emotional learning programs not only showed significant improvements in social-emotional skills and behaviour but also demonstrated an 11-percentilepoint gain in academic achievement.

Cooperative learning is one of the most effective evidence-based strategies for teaching social skills. Other positive benefits from cooperative learning include improvements in academic outcomes (e.g. Johnson and Johnson 2009, Roseth et al. 2008). Other useful strategies for teaching SEL and building positive peer relationships include the use of circle time, classroom meetings, classroom committees, random grouping for small group activities or short-term projects (across each term and year), the use of higher-order thinking tools designed to be used in small groups (e.g. The Ten Thinking Tracks and Under the Microscope. See McGrath and Noble 2010), cross-age extracurricular activities such as orchestra, choir, sporting activities, lunchtime clubs and drama 
performances, the establishment of pro-social peer support structures and the use of Educational Games Tournaments (McGrath and Noble 2010, 2011).

\section{Positive Teacher-student Relationships}

An extensive body of research evidence confirms that positive, respectful and supportive teacher-student relationships contribute to a wide range of desirable student outcomes linked to wellbeing such as attendance (Klem and Connells 2004); engagement and high levels of achievement motivation (e.g.Hattie 2009; Klem and Connell 2004; Martin et al. 2007; Marzano 2003; Roorda et al. 2011); and resilience (Battistich et al. 2004; Nadel and Muir 2005; Raskauskas et al. 2010; Weare 2000). Student behaviour and choices are more likely to be positively influenced by the behaviour and values of trustworthy teachers who provide a secure base (Masten and Obradović 2008). These relationships can support students to set longer-term goals and develop an orientation towards lifelong learning as illustrated in a study of 3,450 students in years 7-12 across six Australian high schools (Martin et al. 2007). Students who believed their teacher accepted and cared for them, were more engaged with learning, felt more confident and motivated to achieve and were more likely to adopt the teacher's goals and expectations. The way in which a teacher responds to socially vulnerable students can also 'set the tone' for how their classmates respond to them and the likelihood of their social inclusion by their classmates (Hughes and Cavell 2001). Resnick et al. (1997), found that young people who reported having a close and positive relationship with their teachers were less likely to use drugs and alcohol, attempt suicide or self-harm, behave in violent ways or engage in sexual behaviour at an early age.

Some of the components of positive and supportive teacher-student relationship may vary according to the age of the student and the level of involvement of the teacher, but the following teacher behaviours have been identified as contributing to such relationships:

- They acknowledge each student, greet them by name and with a smile and notice when they are absent (Benard 2004; Stipek 2006). They intentionally develop positive peer relationships in a way that ensures that no student feels socially isolated (Charney 2002; Donohue et al. 2003).

- They are fair and respectful (Stipek 2006). They take steps to get to know teach student both as a learner (Marzano 2003; Stipek 2006) and also as an individual with a life outside school (Slade and Trent 2000).

- They provide frequent communication, assistance, guidance and positive feedback and try to avoid criticism (Rimm-Kaufman 2011).

\section{Outcomes}

Traditionally schools frame student accomplishment and success in terms of their outcomes such as satisfactory completion of assessment tasks, skill mastery and goal achievement in academic endeavours as well as mastery and development in co-curricular activities such as sports, music, art and drama. The outcomes that students achieve at school contribute significantly to their sense of mastery, competence and accomplishment, a basic psychological need for wellbeing (Niemiec and Ryan 2009). An optimal 
learning environment that promotes academic outcomes and social-emotional learning incorporates effective teaching strategies (e.g. Hattie 2009; Marzano et al. 2001) as well as the explicit teaching of social-emotional skills and personal achievement skills such as persistence, effort, goal-setting, planning and organisational and study skills (McGrath and Noble 2010, 2011).

One of the recurring themes in the large scale meta-analytical reviews of the effects of specific school-based factors on educational outcomes by Hattie (2009) and Marzano et al. (2001) is the importance of the quality of teacher feedback on student outcomes. Good quality teacher feedback helps students to become better skilled at self-regulatory attributes such as self-managing, self-assessing and self-modifying their learning. Dweck's (2006) research into the positive effects of what she has termed a 'growth mindset', has identified that teacher feedback that focuses on the importance of effort and persistence is more likely to be effective in producing desired outcomes than feedback that focuses on 'ability'. Dweck's research is linked to the work by Baumeister and Tierney (2011) on self control or willpower and Duckworth's research on 'grit' (Duckworth and Seligman, 2006).

\section{Strengths}

A focus on strengths in schools encourages the valuing of the different strengths of students, staff and the whole school community collectively. It also promotes the provision of opportunities for everyone to identify, use and further develop their strengths through curriculum opportunities and school-based activities. A 'strength' has been defined as ways of behaving, thinking or feeling that an individual has a natural capacity for, enjoys doing and which allows the individual to achieve optimal functioning while they pursue valued outcomes (Govindji and Linley 2007). The positive education literature has almost exclusively focused on character strengths especially Peterson and Seligman's (2004) values in action (VIA) framework (e.g. Seligman et al. 2009; White and Waters 2014; Quinlan et al. 2014; Proctor et al. 2011). We propose that a strengths-based approach in positive education would be better served by the inclusion of a focus on ability strengths as well as character strengths.

\section{Ability Strengths}

Howard Gardner's (1999) model of multiple intelligences (MI) provides directions for the identification and development of ability strengths. MI theory has been widely adopted in schools since its first publication over 30 years ago (Gardner 1983) and identifies eight intelligences. A differentiated curriculum based on Gardner's multiple intelligences model has been shown to build positive learning communities in which students' value and celebrate different ability strengths. Such an approach is especially useful for students who struggle with academic learning, as it can assist them to achieve more academic success (Kornhaber et al. 2003; McGrath and Noble 2005a, b; Noble 2004). An evaluation of outcomes in forty-one schools that had used MI theory for curriculum differentiation for at least 3 years found significant benefits in terms of student engagement and learning, student behaviour, and parent participation (Kornhaber et al. 2003). This evaluation found particular benefits for students with learning difficulties who demonstrated greater effort in learning, more motivation and improved learning outcomes 
when offered different entry points into the curriculum and opportunities to work in their area(s) of relative strength(s) to demonstrate their understanding of the curriculum. A curriculum-planning tool (MI/Bloom matrix) was developed by McGrath and Noble (1995, 2005a, b) and has helped teachers to plan differentiated learning tasks that focus on different ability strengths. Their use of this matrix in two primary schools enabled all the teachers to successfully identify their students' ability strengths and increased their confidence and skills in diversifying their curriculum tasks to effectively engage their different students in learning (Noble 2004).

\section{Character Strengths}

Character strengths are defined as morally valued traits whose use contributes to fulfilment and happiness (Peterson and Seligman 2004). The VIA model is based on a review of universally valued character traits and incorporates 24 character strengths organised under 6 'virtues'. Quinlan et al. (2014) reported on a six-session classroom-based strengths intervention with 9-12 year old students. After the intervention students demonstrated higher levels of positive affect, classroom engagement, autonomy and relatedness need satisfaction and class cohesion and greater use of their strengths. White and Waters (2014) have outlined the potential benefits of a whole school strengths-based approach for enhancing student wellbeing. They have described how the concept of character strengths has been successfully embedded in English literature classes, in the primary curriculum, in sports coaching, in training students for school leadership positions and in student counselling. The Strath-Haven Positive Psychology program uses the VIA character strengths framework in their Language Arts Classes (Seligman et al. 2009). Pre-test to post-test comparisons showed that the students in these classes compared to students in a control group without a Positive Psychology curriculum reported greater enjoyment and engagement in school. Teachers also reported that the program improved the students' strengths related to learning such as curiosity, love of learning and creativity and parents and teachers reported improvements in the students' social skills. However there were no changes in their depression or anxiety.

\section{Purpose}

Students have a sense of 'purpose' when they perceive that their goals are worthwhile. Having a sense of purpose is closely related to a sense of meaning in life and frequently involves a pro-social or altruistic intent such as a commitment to helping others or improving the world (Hill et al., 2010). Having an identified purpose in life has been shown to be associated with high life satisfaction in adolescents, emerging adults and adults aged 25 years and older (Bronk et al. 2009). Teachers can help students to develop a sense of purpose by providing a meaningful rationale for why a specific learning activity is important and offering students opportunities to make choices in their learning activities. This type of participation addresses students' psychological need for autonomy (Niemiec and Ryan 2009) defined as the desire to engage in self-selected behaviors that align with one's strengths and personality (Deci and Ryan 2000). Skinner et al. (2008) found that students who started the school year high in autonomy were likely to show improvements in their enjoyment and effort as the academic year progressed, 
whereas students low in autonomy were likely to feel increasingly bored, disconnected and frustrated.

One example of empowering students by giving them a 'voice', autonomy and sense of purpose is through their participation in Student Action Teams (Holdsworth et al. 2003). A student action team consists of a group of students who identify and tackle a school or community issue. The team researches the issue, makes plans and proposals and takes action to address it. Schools that have implemented student action teams indicate a substantial positive change in students' curriculum knowledge, and connectedness as well as their engagement at school (Holdsworth et al. 2003). Community service has been shown to enhance students' sense of purpose as well as their academic skills, transfer of knowledge to 'real world situations', critical thinking skills, sense of personal and social responsibility, social-emotional skills and empathy (Hanson et al. 2003; Astin et al. 1999; Eyler and Giles 1999). Other school initiatives that can foster a sense of purpose and meaning include peer support programs and school/class leadership initiatives.

\section{Engagement}

Engagement is a critical concept in education. In the short term student engagement in learning is a good predictor of academic outcomes. In the long term it predicts patterns of attendance, academic resilience and school completion (Jimerson et al. 2003). The link between student engagement, achievement and wellbeing is bi-directional i.e. the more students are actively engaged and achieving in learning, the greater their sense of wellbeing and vice versa (Noble and McGrath Noble et al. 2008a b; Zins et al. 2004). Fredricks et al. (2004) have suggested that engagement can be behavioural, emotional and cognitive engagement. Engagement can also be social (McGrath and Noble 2010). When students are highly behaviourally engaged they are attentive and actively involved in each step and task in the learning process. When they highly emotionally engaged in a learning activity or process in a positive way they are interested, curious, enthusiastic, excited, confident and satisfied with the products of their learning. When students are highly cognitively engaged they are intellectually challenged and stretched and employing critical and creative thinking. When students are highly socially engaged they are positively communicating with their classmates and teacher, cooperating well with a partner or in a team and using social skills such as turn taking, active listening, and negotiating.

\section{Engagement in Terms of FLOW}

Flow Theory posits that optimal learning experiences generate high engagement and positive emotions, are intrinsically motivating and enhance cognitive processing (Csikszentmihalyi 2002; Csikszentmihalyi et al 1993). Csikszentmihalyi (2002) found that when people experienced 'flow' they reported: (a) clear goals and progress toward achieving them; (b) highly focused, effortless, attention or concentration during the activity; (c) a sense of time passing quickly and loss of self-consciousness; and (d) a balance between the challenges of the activity and their ability to meet them (i.e., they felt that their skills were "stretched" to meet the challenge). In a study by Turner et al. (1998), students in three 'high involvement' classes reported significantly more experiences of being in 'flow' than did students in four 'low involvement' classrooms. The study 
highlighted the importance of getting the balance right between the students' level of skill and the degree of challenge presented to them.

\section{Resilience}

All students face adversity at one time or other. Resilience has been defined as "the ability to persist, cope adaptively and bounce back after encountering change, challenges, setback, disappointments, difficult situations or adversity and to bounce back to a reasonable level of wellbeing (McGrath and Noble 2011). It is also the capacity to respond adaptively to difficult circumstances and still thrive". Resilience is crucial for academic and social success in school and in life. Key resilience skills that can be taught to students are: helpful and rational thinking skills, adaptive distancing skills, using humour, optimistic thinking skills, and seeking assistance when needed (McGrath and Noble 2011).

The Penn Resiliency program (PRP) is a well- known resilience program and a metaanalysis of 17 controlled evaluations of the program's impact with young people from 8 to 18 (mostly adolescents) found that most children reported having fewer depressive symptoms (compared to the control group) after the program finished and also at 12-months follow up (Brunwasser et al. 2009). However the reviewers noted that the programs were short term, and mostly conducted in small groups outside school hours by a variety of both school and community-based educators and mental health professionals, researchers and school psychologists. These reviewers queried whether the PRP would be as effective when delivered under real-world conditions rather than controlled research conditions. Two European initiatives recently evaluated the impact of the PRP in school settings. Tak et al. (2014) evaluated the effectiveness of a Dutch version of the PRP with 1,341 students in Year 8 across 9 schools, using a cluster randomized controlled trial design. The program involved 14-15 lessons. They found that the PRP resulted in increased cognitive coping over the course of the follow-up period of 18 months but did not have a positive effect on students' levels of depression, anxiety, hopelessness, happiness or life satisfaction. Challen et al. (2014) evaluated the effectiveness of the PRP in the UK with 2,844 students in total who were arbitrarily assigned to either an intervention or a control group. They found that the intervention group had small reductions in self-reported depressive symptoms but the effect was small and no longer present at the 1-year or 2-year follow-ups. There was no significant impact on symptoms of anxiety or problem behaviour. The researchers concluded that the PPR may be less effective when taught by regular school staff. However this raises the issue of the potential lack of sustainability of any program that is not taught in schools by teachers.

A different approach to teaching resilience is taken in the authors' aforementioned Bounce Back program (McGrath and Noble 2011, 2003). The nine curriculum units utilise children's literature, relational teaching strategies and critical and creative thinking tools to help teachers embed the teaching of wellbeing and resilience in their curriculum and teaching. The implementation of the program in 16 primary schools in Scotland was shown to enhance students' personal resilience skills, social skills and class connectedness. It also enhanced teacher wellbeing and created a more positive school culture (Axford et al. 2011). 


\section{Conclusion}

The new conceptual PROSPER framework has the potential to be used as an organisational tool for the implementation of the seven identified key components of wellbeing. It can be used as a planning tool as well as an audit tool to help schools to identify both current areas of strength as well as practices that might to be further enhanced. Endorsement of the theoretical and evidence-informed seven components of the PROSPER framework has been provided by fourteen academic members of the Institute of Positive Psychology and Education (IPPE) at the Australian Catholic University and fiftyfour educators have also endorsed the potential usefulness of the framework for guiding their adoption of school practices for enhancing student wellbeing. The framework also has the potential to be used within other contexts such as workplaces and other types of organisations and communities.

Authors' contributions

Each author (TN and HM) contributed 50\% to this manuscript. Both authors read and approved the final manuscript.

\section{Author details}

${ }^{1}$ Faculty of Education and Arts, Institute for Positive Psychology and Education, Australian Catholic University, Sydney, Australia. ${ }^{2}$ Deakin University, Melbourne, Australia.

\section{Compliance with ethical guidelines}

Competing interests

The authors declare that they have no competing interests.

Received: 12 March 2015 Accepted: 30 June 2015

Published online: 21 July 2015

\section{References}

Astin, A. W., Sax, L. J., \& Avalos, J. (1999). Long-Term effects of volunteerism during the undergraduate years. Review of Higher Education, 22(2), 187-202.

Axford, S., Schepens, R., \& Blyth, K. (2011). Did introducing the Bounce Back Programme have an impact on resilience, connectedness and wellbeing of children and teachers in 16 primary schools in Perth and Kinross, Scotland? Educational Psychology, 12(1), 2-5.

Banas, J. A., Dunbar, N., Rodriguez, D., \& Liu, S. (2011). A review of humor in education settings: four decades of research. Communication Education, 60(1), 115-144.

Battistich, V., Schaps, E., \& Wilson, N. (2004). Effects of an elementary school intervention on students'"connectedness" to school and social adjustment during middle school. Journal of primary prevention., 24(3), 243-262.

Baumeister, R. F., Campbell, J. D., Krueger, J. I., \&Vohs, K. D. (2005). Exploding the self-esteem myth. Scientific American Mind, 16(4), 50-57.

Baumeister, R. F., \& Tierney, J. (2011). Willpower: why success is the secret of success. UK: Penguin.

Benard, B. (2004). Resiliency: what we have learned. San Francisco: WestEd.

Bennett, M. P., \& Lengacher, C. (2009). Humor and laughter may influence health IV. Humor and immune function. Evidence-Based Complementary and Alternative Medicine, 6(2), 159-164.

Berk, L., Felten, D., Tan, S., \& Bittman, Westengard J. (2001). Modulation of neuroimmune parameters during the eustress of humor-associated mirthful laughter. Alternative Therapies in Health and Medicine, 7, 62-76.

Bishop, S. R., Lau, M., Shapiro, S. L., Carlson, L., Anderson, N. D., Carmody, J., \& Devins, G. (2004). Mindfulness: a proposed operational definition. Clinical Psychology: Science and Practice, 11, 230-241.

Bizumic, B., Reynolds, K. J., \& Turner, J. C. (2009). The Role of the group in individual functioning: school identification and the psychological well-being of staff and students. Applied Psychology. An International Review, 58(1), 171-192.

Blum, R. W., \& Libbey, H. P. (2004). School connectedness—strengthening health and education outcomes for teenagers. Journal of School Health, 74, 231-232.

Bond, L., Carlin, J. B., Thomas, L., Rubin, K., \& Patton, G. C. (2001). Does bullying cause emotional problems? A prospective study of young teenagers. British Medical Journal, 323, 480-484.

Booth-Butterfield, M., \& Booth-Butterfield, S. (2007). Funny students cope better: patterns of humor enactment and coping effectiveness. Communication Quarterly, 55(3), 299-315.

Bronk, K. C., Hill, P. L., Lapsley, D. K., Talib, T. L., \& Finch, H. (2009). Purpose, hope, and life satisfaction in three age groups. Journal of Positive Psychology, 4(6), 500-510.

Brunwasser, S. M., Gillham, J. E., \& Kim, E. S. (2009). A meta-analytic review of the Penn Resiliency Program's effect on depressive symptoms. Journal of Consulting and Clinical Psychology, 77(6), 1042-1054 
Caprara, G. V., Barbaranelli, C., Pastorelli, C., Bandura, A., \& Zimbardo, P. G. (2000). Prosocial foundations of children's academic achievement. Psychological Science, 11(4), 302-306.

Challen, A. R., Machin, S. J., \& Gillham, J. E. (2014). The UK resilience programme: a school-based universal nonrandomized pragmatic controlled trial. Journal of Consulting and Clinical Psychology, 82(1), 75-89.

Charney, R. (2002). Teaching children to care: classroom management for ethical and academic growth, K-8. Greenfield: Northeast Foundation for Children. Available at: Responsive Classroom (http://www.responsiveclassroom.org/ bookstore/index.html).

Colom, G. G., Alcover, C. T., Sánchez-Curto, C., \& Zárate-Osuna, J. (2011). Study of the effect of positive humour as a variable that reduces stress. Relationship of humour with personality and performance variables. Psychology in Spain, 15(1), 9-21.

Csikszentmihalyi, M. (2002). Flow: the classic work on how to achieve happiness. London: Rider.

Csikszentmihalyi, M., Rathunde, K., \& Whalen, S. (1993). Talented teenagers. Cambridge: Cambridge University Press.

Deci, E. L., \& Ryan, R. M. (2000). The" what" and" why" of goal pursuits: Human needs and the self-determination of behavior. Psychological Inquiry, 11(3), 227-268.

Donohue, K. M., Perry, K. E., \& Weinstein, R. S. (2003). Teachers' classroom practices and children's rejection by their peers. Journal of Applied Developmental Psychology, 24(1), 91-118.

Duckworth, A. L., \& Seligman, M. E. (2006). Self discipline gives girls the edge: gender in self-discipline, grades, and achievement test scores. Journal of Educational Psychology, 98(1), 198-208.

Durlak, J. A., Weissberg, R. P., Dymnicki, A. B., Taylor, R. D., \& Schellinger, K. B. (2011). The Impact of enhancing students' social and emotional learning: a meta-analysis of school-based universal interventions. Child Development, 82(1), 405-432.

Dweck, C. S. (2006). Mindset. The new psychology of success. New York: Random House.

Emmons, R. A. (2007). Thanks! How the new science of gratitude can make you happier. New York: Houghton, Mifflin Co.

Emmons, R. A., \& Shelton, C. M. (2002) Gratitude and the science of positive psychology. In C. R. Snyder and S. J. Lopez (Eds.), Handbook of positive psychology (pp. 459-471). NY: Oxford University Press.

Eyler, J., \& Giles, D. (1999). Where's the learning in service-learning. San Francisco: Jossey-Bass Publisher.

Flashpohler, P. D., Elfstrom, J. L., Vanderzee, K. L., et al. (2009). Stand by me: the effects of peer and teacher support in mitigating the impact of bullying on quality of life. Psychology in the Schools, 46, 636-649.

Fredericks, J. A., Blumenfeld, P. C., \& Paris, A. H. (2004). School engagement: potential of the concept, state of the evidence. Review of Educational Research, 74, 59-109.

Fredrickson, B. (2009). Positivity. New York: Crown Publishing Group.

Fredrickson, B. (2013). Positive emotions broaden and build. Advances in Experimental Social Psychology, 47, 1-53.

Fredrickson, B. L., Cohn, M. A., Coffey, K. A., Pek, J., \& Finkel, S. M. (2008). Open hearts build lives: positive emotions induced through loving-Kindness mediation build consequential personal resources. Journal of Personal and Social Psychology, 95(5), 1045-1062.

Fredrickson, B. L., \& Losada, M. F. (2005). Positive affect and the complex dynamics of human flourishing. American Psychologist, 60(7), 678-686.

Fredrickson, B., \& Tugade, M. (2004). Resilient individuals use positive emotions to bounce back from negative emotional experiences. Journal of Personality and Social Psychology, 86(2), 320-333.

Froh, J.J. and Bono, G. (2011). Gratitude in youth: A review of gratitude interventions and some ideas for applications. NASP Communique, 39(5). http://www.nasponline.org/publications/cq/mocq395GratitudeinYouth.aspx.

Froh, J. J., Sefick, W. J., \& Emmons, R. (2008). Counting blessings in early adolescents. An experimental study of gratitude and subjective wellbeing, Journal of School Psychology, 46, 213-233.

Gable, S. J., \& Haidt, J. (2005). What (and why) is positive psychology? Review of General Psychology, 9(2), 103-110.

Gardner, H. (1983). Frames of Mind: the theory of multiple intelligences. New York: Basic Books.

Gardner, H. (1999). Intelligence reframed. Multiple intelligences for the 21st century. Basic Books, NY.

Govindji, R., \& Linley, P. (2007). Strengths use, self-concordance and well-being: implications for strengths coaching and coaching psychologists. International Coaching Psychology Review, 2, 143-153.

Gristy, C. (2012). The central importance of peer relationships for student engagement and well-being in a rural secondary school. Pastoral Care in Education, 30(3), 225-240

Hanson, T., Austin, G., Lee-Bayha, J. (2003). Student health risks, resilience and academic performance in California. Safe and Healthy Kids Program Office, California: West Ed.

Hartup, W. W., \& Stevens, N. (1997). Friendships and adaptation in the life course. Psychological Bulletin, 121, 355-370.

Hattie, J. (2009). Visible Learning: A Synthesis of Over 800 Meta-analyses Relating to Achievement. London: Routledge.

Hill, P. L., Burrow, A. L., Amanda, C. O. D., \& Thornton, M. A. (2010). Classifying adolescents' conceptions of purpose in life. Journal of Positive Psychology, 5, 466-473.

Holdsworth, R., Cahill, S., \& Smith, G. (2003). Student action teams. An evaluation of implementation and impact. Parkville: Faculty of Education, University Melbourne.

Huebner, E. S., \& Hills, K. J. (2014). Assessment of subjective wellbeing in children and adolescents. In D. H. Saklofske, V. L. Schwean, \& C. R. Reynolds (Eds.), The Oxford handbook of child psychological assessment. New York: Oxford Press.

Hughes, J. N., Cavell, T. A., \& Wilson, V. (2001). Further evidence of the developmental significance of the teacher-student relationship. Journal of School Psychology, 39, 289-302.

Huppert, F. A., \& So, T. T. C. (2013). Flourishing across Europe: application of a new conceptual framework for defining well-being. Social Indicators Research, 110(3), 837-861.

Janson, G. R., Carney, J. V., Hazler, R. J., \& Oh, I. (2009). Bystanders reactions to witnessing repetitive abuse experiences. Journal of Counseling and Development, 87, 319-326.

Jimerson, S. R., Campos, E., \& Greif, J. L. (2003). Toward an understanding of definitions and measures of school engagement and related terms. California School Psychologist, 8, 7-27.

Johnson, D. and Johnson, R. (2009). An Educational Psychology Success Story: Social Interdependence Theory and Cooperative Learning. Educational Researcher. 38; 365. http://er.aera.net. 
Keyes, C. L. M. (2002). The mental health continuum: from languishing to flourishing in life. Journal of Health and Social Behavior, 43, 207-222.

Klem, A. M., \& Connell, J. P. (2004). Relationships matter: linking teacher support to student engagement and achievement. Journal of School Health, 74(7), 262-273.

Konishi, C., Hymel, S., Zumbo, B. D., \& Li, Z. (2010). Do school bullying and student-teacher relations matter for academic achievement?: a Multilevel Analysis. Canadian Journal of School Psychology, 25, 19-39.

Kornhaber, M., Fierros, E., \& Veenema, S. (2003). Multiple Intelligences: Best ideas from research and practice. Boston: Allyn and Bacon.

Martin, A. J., \& Dowson, M. (2009). Interpersonal relationships, motivation, engagement, and achievement: yields for theory, current issues and educational practice. Review of Educational Research, 79(1), 344-354.

Martin, A., Marsh, H., Mclnerney, D., Green, J., \& Dowson, M. (2007). Getting along with teachers and parents: the yields of good relationships for students' achievement motivation and self-esteem. Australian Journal of Guidance and Counselling, 17(2), 109-125.

Marzano, R. J. (2003). What works in schools: Translating research into action. Alexandria: Association for Supervision and Curriculum Development.

Marzano, R. J., Pickering, D. J., \& Pollock, J. E. (2001). Classroom instruction that works: Research-based strategies for increasing student achievement. Alexandria: Association for Supervision and Curriculum Development.

Masten, A. S., \& Obradović, J. (2008). Disaster preparation and recovery: lessons from research on resilience in human development. Ecology and Society, 13(1), 9.

Mauss, I. B., Shallcross, A. J., Troy, A. S., John, O. P., Ferrer, E., Wilhelm, F. H., et al. (2011). Don't hide your happiness! Positive emotion dissociation, social connectedness, and psychological functioning. Journal of Personality and Social Psychology, 100(4), 738-748.

McGrath, H., \& T. Noble, (2005a). Eight ways at once. Book one: Multiple intelligences + bloom's revised taxonomy $=200$ differentiated classroom strategies. Sydney: Pearson Education.

McGrath, H., \& T. Noble, (2005b). Eight ways at once. Book two: units of work based multiple intelligences + bloom's revised taxonomy. Sydney: Pearson Education.

McGrath, H., \& Francey, S. (1991). Friendly kids, friendly classrooms. Melbourne: Pearson Ed.

McGrath, H., \& Noble, T. (1995). Seven ways at once. Australia: Longman.

McGrath, H. L., \& Noble, T. (2003). BOUNCE BACK! Classroom Resiliency Program. Melbourne: Pearson Education.

McGrath, H., \& Noble, T. (2010). HITS \& HOTS. Teaching + Thinking + Social Skills. Pearson Education: Melbourne.

McGrath, H. and Noble, T. (2011). BOUNCE BACK! A Wellbeing and Resilience Program. Lower Primary K-2; Middle Primary: Yrs 3-4; Upper Primary/Junior Secondary: Yrs 5-8. Melbourne: Pearson Education.

Meiklejohn, J., Phillips, C., Freedman, M. L., Griffin, M. L., Biegel, G., Roach, A., \& Saltzman, A. (2012). Integrating mindfulness training into K-12 education: fostering the resilience of teachers and students. Mindfulness, 3(4), 291-307.

Miltich, A. P., Hunt, M. H., \& Meyers, J. (2004). Dropout and Violence Needs Assessment: a Follow-up Study. The California School Psychologist, 9, 131-140.

Nadel, J., \& Muir, D. (2005). Emotional Development: Recent Research Advances. Oxford: Oxford University Press.

Niemiec, R. M. (2014). Mindfulness and Character Strengths. Boston, MA: Hogrefe Publishing.

Niemiec, C. P., \& Ryan, R. M. (2009). Autonomy, competence, and relatedness in the classroom. Applying self-determination theory to educational practice. Theory and Research in Education., 7(2), 133-144.

Noble, T. (2004). Integrating the revised bloom's taxonomy with multiple intelligences: a planning tool for curriculum differentiation. Teachers College Record., 106(1), 193-211.

Noble, T., McGrath, H. L. Roffey, S., Rowling, L. (2008a). Scoping Study into Approaches to Student Wellbeing: A Report to the Department of Education, Employment and Workplace Relations. http://www.docs.education.gov.au/system/ files/doc/other/scoping_study_into_approaches_to_student_wellbeing_final_report.pdf.

Noble, T., \& McGrath, H. (2008). The positive educational practices framework: a tool for facilitating the work of educational psychologists in promoting pupil wellbeing. Educational and child psychology, 25(2), 119-134.

Noble, T., \& MCGrath, H. (2015). PROSPER for student wellbeing. Positive Education Pathways and Policy: Springer.

Norrish, J. (2015). Positive education. The Geelong Grammar School Journey: Oxford University Press.

Osterman, K. F. (2000). Students' need for belonging in the school community. Review of Educational Research, 70, 323-367.

Peterson, C. (2013). Pursuing the good life. NY: Oxford University Press.

Peterson, C., \& Seligman, M. E. P. (2004). Character strengths and virtues: A handbook and classification. Oxford: Oxford University Press.

Proctor, C., Tsukayama, E., Wood, A. M., Maltby, J., Eades, J. F., \& Linley, P. A. (2011). Strengths gym: the impact of a character strengths-based intervention on the life satisfaction and well-being of adolescents. The Journal of Positive Psychology, 6, 377-388.

Qualter, P. (2003). Loneliness in children and adolescents: what do schools and teachers need to know and how can they help? Pastoral Care in Education, 21(2), 10-19.

Quinlan, D. M., Swain, N., Cameron, C., \& Vella-Brodrick, D. A. (2014). How'other people matter' in a classroom-based strengths intervention: exploring interpersonal strategies and classroom outcomes. The Journal of Positive Psychology,. doi:10.1080/17439760.2014.920407.

Raskauskas, J., Gregory, J., Harvey, S., Rifshana, F., \& Evans, I. (2010). Bullying among primary school children in New Zealand: relationships with prosocial behaviour and classroom climate. Educational Research, 52(1), 1-13.

Reiss, A. L., Mobbs, D., Greicius, M. D., Eiman, A. A., \& Menon, V. (2003). Humor Modulates the Mesolimbic Reward Centers. Neuron, 40, 1041-1048

Reschly, A. L., Huebner, E. S., Appleton, J. J., \& Antaramian, S. (2008). Engagement as flourishing: the contribution of positive emotions and coping to adolescents' engagement at school and with learning. Psychology in the Schools, 45, 419-431.

Resnick, M. D., Bearman, P. S., \& Blum, R. W. (1997). Protecting adolescents from harm: findings from the national longitudinal study on adolescent health. JAMA, 278, 823-832. 
Rimm-Kaufman, S. (2011). Improving students' relationships with teachers to provide essential supports for learning. American Psychological Association. http://www.apa.org/education/k12/relationships.aspx. Accessed 6 Oct 2014.

Roorda, D. L., Koomen, H. M. Y., Spilt, J. L., \& Oort, F. J. (2011). The influence of affective teacher-student relationships on students'school engagement and achievement: a meta-analytic approach. Review of Educational Research, 8, 493-529.

Roseth, C. J., Johnson, D. W., \& Johnson, R. T. (2008). Promoting early adolescents' achievement and peer relationships: the effects of cooperative, competitive and individualistic goal structures. Psychological Bulletin, 134(2), 223-246.

Rubin, K. H., Bukowski, W., \& Parker, J. (2006). Peer interactions, relationships, and groups. In N. Eisenberg (Ed.), Handbook of child psychology: social, emotional, and personality development (pp. 571-645). New York: Wiley.

Ryff, C. D., \& Singer, B. (1998). The contours of positive human health. Psychological Inquiry, 9, 1-28.

Schonert-Reichl, K. A. (1999). Moral reasoning during early adolescence: links with peer acceptance, friendship, and social behaviors. Journal of Early Adolescence, 19, 249-279.

Schwartz, D., Dodge, K. A., Pettit, G. S., \& Bates, J. E. (2000). Friendship as a moderating factor in the pathway between early harsh home environment and later victimisation in the peer group. Developmental Psychology, 36, 646-662.

Seligman, M. E. (2011). Flourish: A visionary new understanding of happiness and wellbeing. NY: Simon and Schuster.

Seligman, M. E. P., Ernst, R. M., Gillham, J., Reivich, K., \& Linkins, M. (2009). Positive education: positive psychology and classroom interventions. Oxford Review of Education., 35(3), 293-311.

Seligman, M. E. P., Reivich, K., Jaycox, L., \& Gillham, J. (1995). The optimistic child. New York: Houghton Mifflin.

Skinner, E., Furrer, C., Marchand, G., \& Kindermann, T. (2008). Engagement and Disaffection in the classroom: motivational dynamic? Journal of Educational Psychology, 100(4), 765-781.

Slade, M., \& Trent, F. (2000). What the boys are saying: An examination of the views of boys about declining rates of achievement and retention. International Education Journal, 1(3), 201-229.

Stanley, M., \& McGrath, H. (2006). Buddy systems: Peer support in action. In H. McGrath \& T. Noble (Eds.), Bullying solutions; evidence-based approaches for Australian schools. Sydney: Pearson Education.

Stipek, D. (2006). Relationships matter. Educational Leadership, 64(1), 46-49.

Strom, I. F., Thoresen, S., Wentzel-Larsen, T., \& Dyb, G. (2013). Violence, bullying and academic achievement: a study of 15 year old adolescents and their school environment. Child Abuse and Neglect, 37(6), 243-251.

Tak, Y. R., Kleinjan, M., Lichtwarck-Aschoff, A., \& Engels, R. C. (2014). Secondary outcomes of a school-based universal resiliency training for adolescents: a cluster randomized controlled trial. BMC Public Health., 14, 1171.

Turner, J. C., Meyer, D. K., Cox, K. E., et al. (1998). Creating contexts for involvement in mathematics. Journal of Educational Psychology, 90, 730-745.

Weare, K. (2000). Promoting mental, emotional and social health: a whole school approach. NY: Routledge.

Wentzel, K. R., Barry, C., \& Caldwell, K. (2004). Friendships in middle school: influences on motivation and school adjustment. Journal of Educational Psychology, 96, 195-203.

White, M., \& Waters, L. E. (2014). A case study of'The Good School:'Examples of the use of Peterson's strengths-based approach with students. The Journal of Positive Psychology,. doi:10.1080/17439760.2014.920408.

Zins, J. E., Weissberg, R. P., Wang, M. C., \& Walberg, H. J. (Eds.). (2004). Building Academic Success on Social and Emotional Learning: What Does the Research Say?. New York: Teachers College Press.

Zweyer, K., Velker, B., Ruch, W. (2004). Do cheerfulness, exhilaration, and humor production moderate pain tolerance? A FACS study. Humor: International Journal of Humor Research, 17(2), 85-119.

\section{Submit your manuscript to a SpringerOpen ${ }^{\circ}$ journal and benefit from:}

- Convenient online submission

- Rigorous peer review

- Immediate publication on acceptance

- Open access: articles freely available online

- High visibility within the field

- Retaining the copyright to your article

Submit your next manuscript at $\boldsymbol{\nabla}$ springeropen.com 